\title{
Relasi Politik dan Isu Agama: Dinamika Politik PKS dan Aksi Bela Islam pada Pemilu Serentak 2019
}

Nabil Lintang Pamungkas*, Agung Widiyantoro, Moddie Alvianto Wicaksono

nabilpamungkas16@mail.ugm.ac.id, a.widiyantoro@mail.ugm.ac.id, moddie.wicaksono@gmail.com

${ }^{12}$ Departemen Politik dan Pemerintahan Universitas Gadjah Mada

${ }^{3}$ Departemen Komunikasi Universitas Ahmad Dahlan

\begin{abstract}
Abstrak
Tulisan ini meyakini kecenderungan penggunaan isu agama sebagai instrumen politik dalam momentum pemilihan umum di Indonesia. Beberapa riset mengatakan isu agama menjadi faktor pendukung terjadinya polarisasi dalam masyarakat dan mempengaruhi subjektivitas pemilih dalam menentukan perwakilan aspirasinya. Penulis tertarik pada konsistensi dukungan politik Partai Keadilan Sejahtera (PKS) terhadap Aksi Bela Islam yang mengemuka sebagai gerakan yang mengangkat isu penistaan agama dan kriminalisasi Ulama. Penelitian ini bertujuan menganalisis potensi PKS menggunakan isu agama sebagai instrumen politik untuk memperoleh dan memperkuat dukungan dalam pemilu. Penelitian ini menggunakan metode kepustakaan yang di dalamnya terdapat beberapa literatur dan sumber ilmiah yang relevan terhadap fokus permasalahan. Relasi politik yang terbentuk melalui isu agama antara PKS dengan Aksi Bela Islam sejak 2016 hingga Pemilu 2019 begitu dinamis. Hasil penelitian memaknai sikap politik PKS terhadap Aksi Bela Islam sebagai (1) dukungan politik yang mencerminkan praktik demokrasi Indonesia, (2) PKS menyerukan umat Islam untuk berpartisipasi aktif dalam setiap agenda Aksi Bela Islam, dengan mentaati dan mengikuti fatwa para tokoh-tokoh Islam yang disampaikan dalam forum aksi tersebut, dan (3) PKS menyerukan untuk tidak memilih pemimpin yang telah melakukan kriminalisasi terhadap Ulama. Dengan demikian, studi menunjukkan bahwa PKS mempunyai kepentingan elektoral di balik relasi politik dengan Aksi Bela Islam dengan memanfaatkan isu agama.
\end{abstract}

Kata Kunci: agama, Aksi Bela Islam, pemilu, PKS, politik.

\begin{abstract}
This paper believes the tendency to use religious issues as a political instrument in the momentum of elections in Indonesia. Some research said the issue of religion is a supporting factor for polarization in society and influences the subjectivity of voters in determining the representation of their aspirations. The author is interested in the consistency of the Prosperous Justice Party (PKS) political support for the Aksi Bela Islam (Islamic Defending Action) which emerged as a movement that raised the issue of blasphemy and the criminalization of Ulama. This study aims to analyzing the potential of PKS using religious issues as political instruments to obtain and strengthen support in elections. This research uses a library method in which there are several literatures and scientific sources that are relevant to the focus of the case. Political relations formed through religious issues between PKS and Aksi Bela Islam from 2016 to the 2019 Election were so dynamic. The results of the study interpret the PKS's political attitude against Aksi Bela Islam as (1) political support that reflects the practice of Indonesian democracy, (2) PKS calls on Muslims to actively participate in every agenda of the Aksi Bela Islam, by obeying and following the fatwas of Islamic leaders who delivered in the forum, and (3) PKS calls for not choosing leaders who have criminalized Ulama. Thus, studies show that PKS has an electoral interest behind political relations with Aksi Bela Islam by utilizing religious issues.
\end{abstract}

Keywords: religion, Aksi Bela Islam, elections, PKS, politics.

\section{Pendahuluan}

Tulisan ini hendak menguji bagaimana relasi yang terbentuk antara Partai Keadilan Sejahtera (PKS) dengan Gerakan Aksi Bela Islam melalui isu atau sentimen identitas yang

\footnotetext{
${ }^{*}$ Corresponding Author: Nabil Lintang Pamungkas, Pascasarjana Politik dan Pemerintahan, Fakultas Ilmu Sosial dan Ilmu Politik, Universitas Gadjah Mada Yogyakarta, Jl. Sosio Yustisia No.1, Yogyakarta 55281.
} 
berkembang saat momen kontestasi pemilihan umum 2019. PKS dianggap relevan karena memiliki karakteristik yang serupa dengan gerakan Islam dan konsisten mendukungnya. Keduanya pun selaras menggunakan asas Islam sebagai alat perjuangan politik. Kemunculan PKS sebagai partai baru di Indonesia merupakan fenomena yang menarik, pasalnya, embrio organisasi tersebut berasal dari corak pemikiran politik Islam Timur Tengah. Hal ini merupakan gerakan politik Islam baru pasca-reformasi. Tidak hanya kehadiran partai Islam, kemunculan partai baru juga diikuti dengan partai-partai sekuler yang merasa mengalami nasib serupa yakni tindakan represif kekuasaan Orde Baru, sebagaimana Dhakidae (1999) menjelaskan bahwa konstelasi parpol pasca-reformasi memisahkan dua kutub secara tajam; antara kutub vertikal (berbasis aliran/agama) dan kutub horizontal (berbasis kelas). Kehadiran gerakan arus bawah baik berbasis aliran maupun kelas merupakan sebuah upaya ekspresi kebebasan yang selama ini terkekang geraknya oleh kekuasaan otoriter (Heryanto, 2018). Hal tersebut yang memungkinkan teraktualisasi melalui jalur politik parlemen dengan mendirikan partai baru yang memiliki variasi ideologi. Momen yang mendasari berdirinya PKS adalah kondisi di mana negara tidak mengakomodir kepentingan umat Islam (Rahmat, 2008). Perlakuan tersebut mendapat respons dari para pelopor PKS dengan melakukan misi dakwah Islam melalui masjid-masjid kampus, yang di dalamnya terdapat aktivis muslim berusia muda yang memiliki resistensi dengan Orde Baru.

Dalam penghitungan pemilu 2019, PKS terbilang cukup sukses jika dibandingkan dengan partai Islam lainnya. PKS memperoleh suara sebesar 8,21 persen. Hal ini dianggap sebagai kesuksesan terbesar bagi PKS dalam sejarah pemilu di Indonesia. Tesis Mietzner (2008) mencoba membandingkan dinamika partai politik pada pemilu 1955 dan pasca-reformasi. Mietzner menjelaskan bahwa partai politik dalam pemilu 1955 cenderung bersifat sentrifugal, artinya parpol cenderung tidak berkontestasi di ranah pusat kekuasaan tetapi kontestasi berada di level masyarakat. Artinya, peranan partai politik dalam kontestasi pemilu bergerak di level massa, antar partai politik cenderung mengalami benturan ideologis yang kuat dengan melibatkan massa sebagai penopang kekuatan utamanya dalam memperoleh dukungan suara. Sedangkan pasca-reformasi bergeser dari sentrifugal menuju sentripetal. Parpol lebih mementingkan kontestasi di ranah pusat. Kontestasi antarpartai tidak mengalami friksi yang kuat, sebab bersifat negosiasi dan cenderung bersifat transaksional. Dengan demikian, secara tidak langsung parpol mulai terkartelisasi. Namun, hadirnya PKS justru bersifat sentrifugal yang mendekatkan diri terhadap kelompok-kelompok Islam di level massa melalui politik dakwah.

Sebagai upaya mengembalikan dinamika partai politik yang berkonsentrasi pada kekuatan massa, PKS berupaya membangun relasi politik dengan gerakan Islam yang sedang berkembang, misalnya, FPI, HTI maupun GNPF-MUI yang semuanya ikut tergabung dalam Aksi Bela Islam (Pamungkas \& Octaviani, 2017). Gerakan Islam tersebut merupakan fenomena menarik dalam konstelasi politik Indonesia, gerakan tersebut mampu memobilisasi massa dengan memusatkan pada satu isu yaitu menolak pemimpin non-Islam. Elemen yang terlibat terdiri dari kelompok Islam moderat, kelompok Islam moderat-konservatif, kelompok Islam garis keras, masyarakat miskin perkotaan korban penggusuran, dan kelompok sekuler. Masing-masing kelompok Islam yang terlibat memiliki perbedaan cara pandang dalam beberapa praktik menjalankan ibadah dan metode berdakwah (Kusumo \& Hurriyah, 2018). Hadiz (2019) melihat gerakan tersebut sebagai sebuah fenomena populisme Islam di Indonesia, karena bervariasinya aliansi kelas atau kelompok yang 
terlibat sehingga berhasil membentuk sebuah gerakan Islam baru. Pasalnya koalisi awal yang terbentuk dari gerakan Aksi Bela Islam tersebut sangat bersifat heterogen.

Selain itu, wacana yang dibangun adalah negara dan agama saling bertautan karena telah termaktub dalam ajaran Islam. Inisiator dari gerakan tersebut adalah Front Pembela Islam (FPI) yang dipimpin oleh Habib Rizieq Shihab dan Gerakan Nasional Pengawal Fatwa Majelis Ulama Indonesia (GNPF-MUI). Sejak awal, isu yang dibangun bersifat politis dan memiliki kaitan dengan politik elektora sehingga gerakan tersebut kerap kali mendapatkan dukungan moral dari beberapa partai politik, salah satunya PKS. Menjelang pemilu 2019, PKS telah berhasil mengambil momentum di tengah menguatnya isu agama. Hal ini dibuktikan dengan pernyataan elite PKS yang mengatakan bahwa hanya partainya sangat konsisten dalam memperjuangkan dakwah Islam sehingga perolehan suaranya naik secara signifikan (Maulidar, 2019). Menurut beberapa pengamat politik, PKS merupakan sebuah jawaban yang tepat dalam menghadapi persoalan umat muslim sekarang. Terlebih, umat muslim membutuhkan kendaraan politik yang setia dan konsisten dalam memperjuangkan hak politiknya (Junita, 2019). Melonjaknya suara PKS juga disebabkan kesamaan sikap politik dari pemilih Islam yang tergabung dalam gerakan tersebut sehingga PKS dianggap sebagai referensi utama pemilih Islam dalam memilih partai politik.

Tulisan ini bertujuan untuk melihat bagaimana terbentuknya relasi politik antara PKS dan gerakan Islam yang berkelindan dengan narasi agama selama pelaksanaan Pemilu 2019. Sebagai partai yang konsisten di jalur dakwah Islam, PKS acap kali dianggap sebagai dalang ketegangan politik karena menggunakan isu agama untuk menyerang lawannya maupun meningkatkan keterpilihannya di parlemen. Contohnya, Pilkada DKI Jakarta tahun 2017. Setidaknya ada beberapa alasan yang mendasari. Pertama, Pilkada DKI Jakarta dianggap sebagai momen krusial bagi partai politik. Parpol menganggap bahwa dengan memenangkan kepala daerah ibu kota akan membuat popularitas partainya naik. Kedua, maraknya isu agama yang gencar digunakan oleh beberapa kelompok Islam untuk menyerang figur dari seorang kandidat maupun partai politik yang mengusungnya.

Bagian pertama, tulisan ini menyajikan perdebatan teoritik bagaimana relasi antara parpol dan gerakan sosial. Salah satu penyokong utama dalam keterpilihan parpol adalah masifnya gerakan-gerakan sosial yang mampu membentuk wacana dalam memobilisasi pemilih untuk memilih kandidat yang diusungnya (Poguntke, 2000). Bagian kedua, tulisan ini memunculkan isuisu yang berkaitan dengan keagamaan yang menyeruak pada proses elektoral. Selanjutnya, penulis menyajikan gambaran mengenai relasi kuasa yang terbentuk antara PKS dengan aktor gerakan Islam kontemporer. Di bagian terakhir, penulis melakukan sebuah analisis apakah isu agama yang sedang berkembang merupakan perjuangan politik PKS dalam mengembalikan politik Islam di Indonesia atau sebaliknya.

\section{Relasi Partai Politik, Organisasi dan Gerakan Sosial}

Pada dasarnya, partai politik 'menggunakan' organisasi lain yang relevan dalam membentuk lingkungan mereka untuk menciptakan hubungan dengan berbagai kelompok pemilih potensial (Lawson, 1980; Poguntke, 2000; Poguntke, 2005). Inti dari relasi tersebut adalah suara pemilih yang ditukar atau dikonversi menjadi kebijakan atau janji tertentu. Pertukaran tersebut berdasarkan negosiasi yang bersifat permanen dan diformalisasikan antara elit partai dan elit organisasi dengan konsesi kebijakan dari partai yang dijual untuk mobilisasi dukungan dari 
organisasi atau gerakan pendukung (Poguntke, 2000). Dari perspektif partai politik, mereka berfungsi sebagai collateral organizations untuk menjangkau kepentingan sosial tertentu. Oleh karena itu, mereka yang peduli pada suatu isu dan minat tertentu merasa lebih tertarik untuk berpartisipasi dengan organisasi kepentingan yang lebih relevan dibandingkan partai. Dengan membuat ikatan dengan organisasi kolateral, partai politik mampu untuk memperluas basis dukungan di masyarakat di luar konstituen inti mereka (Duverger, 1964; Beyme, 1980). Oleh karena itu, mereka bisa memperoleh stabilitas suara dalam proses elektoral (Webb, 1992; Lane \& Ersson, 1987).

Secara historis, relevansi dukungan organisasi massa dan partai politik memiliki konteks yang panjang di Indonesia. Partai-partai politik di Indonesia, pada era Orde Lama, terkait dengan gerakan di level pelajar dan mahasiswa, buruh, petani, dan perempuan berdasarkan instruksi Soekarno kepada seluruh organisasi massa agar merapatkan diri kepada salah satu partai politik (Wieringa, 2010). Polarisasi ideologis yang mengental pada masa Orde Lama ini disebabkan oleh kontestasi dan perebutan pengaruh di level masyarakat sehingga partai bersifat sentrifugal (Mietzner, 2008). Pergeseran terjadi ketika memasuki era Orde Baru yang melakukan depolitisasi massa, sehingga selain partai politik tidak diperkenankan untuk melakukan kegiatan politik, termasuk organisasi sayap kecuali yang direstui oleh pemerintah. Kultur patrimonialisme dan depolitisasi massa ini tak lagi menyebabkan partai non Golkar dan ABRI menghadapi tekanan dari pemerintah (Crouch, 1979).

Partai politik yang bersifat sentripetal pasca Orde Baru merupakan konsekuensi atas pertarungan di tingkat elite dan kompromi politik di belakangnya. Partai menjadi kelompok intermediary dengan organisasi dan gerakan sosial yang berafiliasi secara langsung atau tidak langsung dengan relasi yang lebih cair. Poguntke (2006) berpendapat bahwa ada perbedaan hubungan yang terjalin antara partai-organisasi dan partai-gerakan sosial baru. Gerakan sosial baru ditandai dengan ketiadaan pemimpin formal yang membuat relasi antara partai politik dengan gerakan sosial sulit untuk dilihat mana yang lebih dominan kepentingannya; apakah partai politik atau gerakan sosial? Dalam hal ini, gerakan Islam kontemporer yang dicirikan antara revivalisme atau fundamentalisme melihat ini lebih luas sebagai jejaring daripada relasi yang lebih terstruktur kaku dan formal antara partai dan gerakan sosial yang disatukan oleh lebih banyak persamaan simbolis dan sedikit perbedaan (Neidhardt \& Rucht, 1993). Gerakan sosial baru yang ditandai dengan ketiadaan elit pemimpin membuat ikatan tersebut lebih cair untuk menjaga otonomi dan berjarak dengan partai politik.

Partai politik berharap, dengan menjalin relasi yang lebih luas dengan gerakan sosial, selain organisasi formal, dapat meningkatkan stabilitas dalam proses elektoral. Alasannya gerakan sosial baru mempunyai kepentingan agregat yang kecil sehingga dapat lebih diterima oleh masyarakat. Mereka berupaya untuk menghilangkan sekat-sekat ideologis dan menciptakan pluralitas strategi untuk mencapai hasil yang maksimal. Relasi yang bagus dengan gerakan sosial dapat menjadi asset signifikan dalam fase mobilisasi protes (Poguntke, 2006).

\section{Metode Penelitian}

Metode penelitian yang digunakan dalam penelitian ini menggunakan metode penelitian kepustakaan (library research). Metode ini dapat diartikan sebagai suatu rangkaian kegiatan yang berkenaan dengan metode pengumpulan data pustaka, membaca, dan mencatat serta mengolah bahan penelitian (Mustika, 2008). Jenis penelitian ini bersifat kualitatif, dengan 
melakukan teknik pengumpulan data dari beberapa buku, artikel ilmiah yang terkait. Langkah awalnya dengan mengidentifikasi bahan bacaan penulis yang sekiranya relevan dan dapat digunakan sebagai rujukan utama dalam membahas persoalan ini. Selanjutnya dengan melakukan analisis terhadap bahan bacaan tersebut sehingga penulis dapat menyimpulkan persoalan apa saja yang akan dikaji.

\section{PKS dan Gerakan Islam Pasca Reformasi}

Periode 1980-1990-an adalah periode tumbuhnya arus Islamisme baru di Indonesia dalam bentuk wacana dan kelompok diskusi Islam di kampus sekuler. Kebangkitan Islam di kampuskampus sekuler yang terjadi pada tahun 1980-an terkait erat dengan perubahan sosial yang melanda masyarakat Indonesia. Perubahan sosial itulah adanya gelombang modernisasi yang menerjang masyarakat Indonesia. Modernisasi yang dijalankan Orde Baru membawa implikasi yang bertolak belakang. Modernisasi, di satu sisi, melakukan peminggiran terhadap kekuatan politik Islam, namun di sisi yang lain membawa berkah terselubung (blessing in disguised) berupa Islamisasi masyarakat Indonesia (Arrobi, 2020). Gelombang Islamisasi yang terjadi pada tahun 1980 terjadi karena adanya gairah masyarakat Indonesia, terutama kalangan menengah Muslim perkotaan dan terdidik di kampus-kampus sekuler/negeri dan pulangnya alumni Timur Tengah yang berdampak terhadap meningkatnya gairah keislaman di Indonesia.

Setelah tahun 1998, kebebasan berekspresi dan berorganisasi tumbuh seperti cendawan di musim hujan. Gerakan sosial, termasuk gerakan Islam yang sebelumnya bergerak di bawah tanah era Soeharto berganti menjadi terbuka. Fenomena tersebut ditandai dengan munculnya ragam partai politik dan organisasi massa kontemporer berbasis Islam di luar arus utama organisasi utama yang bersifat moderat seperti NU, Muhammadiyah, Nahdlatul Wathan dan lain-lainnya. Berger (1999) melihat bahwa gerakan kebangkitan Islam (Islamic revival) merupakan salah satu gerakan sosial penting pada abad ke-21. Fenomena ini terjadi karena di beberapa negara Timur Tengah dan Asia Tenggara merupakan negara berpenduduk Muslim “turunan" sehingga agama menjadi sebuah budaya dibanding sebagai sebuah sumber petunjuk praktis dari umat Islam (Carvalho, 2009). Carvalho (2009) berpendapat bahwa faktor deprivasi ekonomi menjadi salah satu faktor kunci yang menjadikan gerakan revivalisme Islam tumbuh di negara-negara dunia ketiga.

Dari kelompok muslim ini kemudian menjelma dalam dunia politik berbasis Islam modernis dan hal ini terbilang sebagai model Islam baru di Indonesia. Representasi NU dan Muhammadiyah sebagai kelompok Islam mainstream dianggap tidak konsisten dalam mengubah masyarakat menjadi lebih kaffah dalam berislam (Adiwilaga, 2017). Kemudian, gerakan tersebut melakukan misi dakwah di dunia pendidikan melalui organisasi kampus, seperti Dewan Dakwah Islamiyah Indonesia (DDII), Forum Silaturahmi Lembaga Dakwah Kampus (FSLDK), serta Kesatuan Aksi Mahasiswa Muslim Indonesia (KAMMI) yang cenderung mengadopsi pemikiran politik Islam, Ikhwanul Muslimin (IM). Dalam kontestasi politik, ketiganya memiliki afiliasi dengan PKS. Pemikiran IM diadopsi oleh para elite PKS dengan menegaskan bahwa urusan duniawi (termasuk urusan negara) merupakan bagian dari ajaran Islam (Rahmat, 2008). Islam dijadikan sebagai sumber segala sumber hukum dalam suatu negara. Pemikiran tersebut berasal dari Hasan Al-Banna yang merupakan pelopor IM Mesir. Pemikirannya diadopsi dan ditransformasikan pada praktik politik di Indonesia (Aminuddin \& Masykuri, 2016). Oleh karena itu, PKS mengikuti pola perkaderan IM, dengan melakukan gerakan politik berbasis pengetahuan. 
Konsistensi gerakan ini perlahan mengalami pergeseran menuju dunia politik dengan mendirikan Partai Keadilan (PK) yang pada akhirnya berubah nama menjadi PKS. Gerak politiknya cenderung berada dalam lingkungan sosial yang terbatas. Sebagaimana yang dikatakan Arobbi (2020) anggota dari kelompok Islam ini mayoritas merupakan alumni lembaga pendidikan di Timur Tengah. Salah satu aktivisnya bernama Salim Segaf Al-Jufri yang merupakan petinggi utama di internal PKS (Lihat Salman dalam Aminuddin \& Masykuri, 2016). Pola perkaderan PKS dan gerakan Tarbiyah (pendidikan Islam) memusatkan diri pada pola pendidikan Islam melalui ruangruang diskusi kecil, yang beranggotakan lima sampai dua belas orang dengan mendapatkan bimbingan keislaman oleh ustaz yang memiliki pemikiran serupa (murabbi). Pola komunikasi yang dilakukan murabbi terhadap mutrabbi lebih bersifat sistematis, tidak boleh keluar dari kurikulum yang telah ditetapkan. Sehingga pola yang terbentuk cenderung bersifat top-down.

Pendirian PKS sebagai partai politik dapat dilihat dari upaya gerakan Tarbiyah untuk melakukan misi dakwah berupa Islamisasi di Indonesia melalui jalur politik. Dengan memperebutkan kursi parlemen dan pemerintahan, maka hal tersebut dianggap sebagai jalan pintas dalam menerapkan konsep Islam di Indonesia. Pada pemilu 2004 dan 2009, PKS berhasil meraih kursi parlemen. Keberhasilan PKS tidak terlepas dari peran partai secara institusi yang menyatakan sikapnya sebagai partai yang inklusif, yang sebelumnya dianggap partai yang cenderung mengeksklusifkan diri dengan kelompok Islam (Aminuddin, 2010).

PKS tidak menyerukan dakwah-dakwah Islamiyah dalam strategi politiknya tetapi partai ini cenderung menggunakan isu yang bersifat populis, seperti "partai bersih", "partai antikorupsi”. Dengan isu tersebut, suara PKS naik dengan mendapatkan 7,8 persen suara. Tidak seperti saat awal pendiriannya yang secara terbuka menyuarakan sebagai representasi umat muslim, di tengah perjalanannya, PKS banyak melakukan modifikasi terhadap gerak politik dakwahnya. Di saat kepemimpinan Susilo Bambang Yudhoyono (SBY), PKS dalam setiap perumusan kebijakan, cenderung berkoalisi dengan partai-partai sekuler. Modifikasi diri yang dilakukan PKS dimotori Presiden PKS saat itu, Hidayat Nur Wahid. PKS mengklaim bahwa ini sebagai salah satu upaya strategi politik (siyasah) untuk mempertahankan organisasinya dari ancaman ambang batas lolos parlemen.

Namun semenjak Pilkada Serentak, kecenderungan sikap politik PKS cenderung kembali mengarah pada eksklusivitas ajaran Islam. Politik berbasis identitas keagamaan mulai marak bermunculan, identitas keagamaan dijadikan sebagai upaya membangun solidaritas dalam kehidupan politik kontemporer (Horowitz, 1985). Elite politik menggunakan politik identitas daripada memunculkan ide perubahan sosial untuk meraih suara pemilih (Afala, 2018). Kini, PKS kembali ke jalur lama. Memunculkan ide dan semangat keislaman yang bersinergi di dalam Aksi Bela Islam.

\section{Sentimen Agama Pasca Pilkada Serentak Sebagai Momentum}

Pemilu 2019 merupakan pemilu yang mengundang banyak perhatian. Selain karena digelar secara serentak, disinyalir isu yang berkembang adalah sentimen agama. Hal ini mengacu pada kasus pilkada, dua tahun sebelum pemilu digelar. Salah satu yang menjadi pembicaraan masyarakat Indonesia adalah Pilkada DKI 2017. Saat itu, isu agama dengan mudah diembuskan dan ditujukan kepada Basuki Tjahaja Purnama (Ahok), yang saat itu bertarung melawan Anies Baswedan dan Agus Yudhoyono. 
Ahok dicitrakan oleh rival sebagai orang yang menistakan Islam sehingga membuat berbagai kelompok Islam protes dan menyudutkannya. Citra tersebut berhasil diterapkan sehingga narasi agama seakan menjadi nilai ampuh bagi partai politik yang berlaga pada Pemilu 2019. Apalagi melihat jarak antara pilkada dengan pemilu hanya rentang dua tahun (Bonasir, 2017). Narasi tersebut dipupuk dan dirawat oleh kelompok Islam agar nantinya digunakan sebagai strategi memobilisasi pemilih.

Sentimen agama mencapai titik kulminasinya ketika kelompok Islam menyuarakan pendapatnya lewat aksi gerakan protes di Monas atau yang lebih sering disebut sebagai "Gerakan Aksi Bela Islam 212" yang pada akhirnya muncul gerakan Islam lainnya seperti Persatuan Alumni 212 (PA-212), Reuni 212, Ijtima' Ulama, dan sebagainya. Hal ini kemudian menjadi faktor determinan bagi kelompok Islam terhadap keputusan politiknya di tingkat pemilu presiden dan legislatif. Dari beberapa partai politik yang sedang bertarung, PKS merupakan salah satu partai yang begitu gencar mendukung serta merawat narasi tersebut. Narasi agama yang dibawa saat itu adalah menolak pemimpin birokrat yang beragama selain Islam. Dalam pilkada DKI Jakarta 2017, secara tidak langsung PKS mendukung untuk memberikan hukuman yang seadil-adilnya bagi Ahok yang dianggap melakukan penistaan terhadap Islam. Ahok, yang saat itu masih menjabat sebagai Gubernur Jakarta, melakukan sosialisasi terhadap warganya di Kepulauan Seribu dengan mengutip surah Al-Maidah ayat 51. Respons negatif bergelimpangan yang kemudian muncul spandukspanduk yang melarang pemilih Islam memilih pemimpin yang non-Islam (Viva.co.id, 2017).

Dikutip dari beberapa portal berita daring, sebagian politisi PKS tidak menyangkal apabila partainya dianggap sebagai partai yang menggunakan narasi agama sebagai strategi politiknya. Seperti yang telah ditanggapi oleh petinggi PKS, yang secara tegas tidak menolak hadirnya politik identitas berbasis agama. Pernyataan Mardani Ali Sera salah satunya yang mengatakan bahwa "Politik identitas tak selamanya negatif. Ketika seorang muslim ingin agar ajaran Islam-nya terimplementasi dalam kehidupan sehari-hari, itu bukan politik. identitas yang buruk”" (Kumparan, 2019).

Pilkada lainnya juga mengalami hal serupa, yakni Pilgub Sumut 2018. Pilgub ini menjadikan paslon Edy-Musa sebagai pemenang dengan mengalahkan paslon Djarot-Sihar. PKS yang mendukung paslon Edy-Musa juga memiliki keterikatan dengan isu agama, dengan munculnya Kongres Umat Islam (KUI) yang digelar di Medan. Shohibul Iman, Presiden PKS, mengatakan bahwa terselenggaranya KUI ini ditujukan untuk membincangkan Pilgub Sumut (Pepinsky, 2019), yang kemudian hasilnya dirangkum dalam Piagam Umat Islam Sumatera Utara, dan salah satu poin piagam tersebut menyerukan kepada rakyat Sumut untuk memilih paslon muslim-muslim. Tentu saja hal ini merugikan dan merupakan negative campaign bagi paslon yang diusung PDIP dan PPP, sebab cawagub yang diusungnya merupakan seorang nonmuslim.

Dalam Pilkada lainnya seperti Jabar, juga memiliki keterikatan antara preferensi pemilih dengan agama yang dianut oleh kandidat. Survei yang dirilis Poltracking menjelaskan bahwa faktor agama yang dianut kandidat paslon cukup besar jika dibandingkan dengan rekam jejak paslon (Poltracking, 2017). Angka yang ditunjukkan cukup tinggi, masyarakat yang memilih kandidat berdasarkan agamanya sebesar 67 persen, sedangkan pengaruh rekam jejak berada di angka 66,9 persen. Semakin kuatnya sentimen isu agama yang juga sebanding dengan peran kelompokkelompok agama menyebabkan potensi yang tinggi dalam hal memobilisasi massa dalam urusan politik elektoral (Mujani, Liddle, \& Ambardi, 2019). 


\section{Dinamika Politik PKS dan Aksi Bela Islam}

Sejak mula pemilu 2019, PKS mencoba menggunakan narasi Islam sebagai langkah politiknya dalam pertarungan politik elektoral. Dalam gerak politiknya, PKS mengklaim sebagai partai yang dapat menjawab kegagalan dari partai berbasis sekuler yang cenderung memisahkan secara dikotomis antara persoalan negara dan agama. Bagi PKS, Islam dan politik merupakan satukesatuan yang tidak dapat terpisahkan. Hal ini tertuang dalam visi-misi yang menjadi platform partai tersebut. Secara tegas PKS mengklaim dirinya sebagai partai dakwah yang berjuang atas nama penegak keadilan dan kesejahteraan dalam bingkai persatuan ummat dan bangsa (PKS, 2019). Model rekrutmen dan kaderisasi politik PKS juga berbeda dengan partai lainnya, gerakan sayap partai berbasis dakwah dilakukan melalui forum-forum pengaiian seperti liqa' dan balaqah.

Perjalanan dakwah yang dilakukan PKS lebih cenderung mengarah kepada masyarakat perkotaan, yang dimaksud adalah masyarakat yang secara pengetahuan lebih terbuka. PKS, dalam sejarah berdirinya, memiliki persinggungan erat dengan organisasi-organisasi dakwah di dalam kampus. Perjalanan dakwah PKS dinilai sebagai jawaban atas kegelisahan masyarakat terkait hak kewarganegaraannya yang secara umum tidak terakomodir oleh negara. Maka dari itu, PKS membentuk ruang-ruang politik baru berbasis keagamaan untuk mewadahi kegelisahan masyarakat.

Gerakan berbasis identitas dapat tumbuh dari kalangan masyarakat karena mereka merasa tersingkirkan dalam diskursus kewarganegaraan. Mereka tidak diakomodir secara politik oleh negara sehingga politik identitas hadir sebagai ruang alternatif baru bagi masyarakat (Stokke, 2013). Hadiz (2019) dalam menjelaskan fenomena populisme Islam semacam kumpulan entitas politik antarkelas, dan kelas yang dimaksud adalah kepemilikan secara materi. Namun, tesis Hadiz menuai banyak pertentangan di antara para ilmuwan politik, yang secara implisit mengatakan bahwa gerakan populisme Islam tidak terdiri dari aliansi antarkelas, namun persoalan transenden yang menyatukan gerakan tersebut.

Apabila ditarik dalam persoalan identitas agama yang terjadi pada kontestasi politik elektoral justru menjadi kekhawatiran tersendiri, dalam hal ini adalah dampak dari polarisasi yang terjadi di masyarakat. Hasil riset penelitian yang dirilis oleh World Economic Forum terkait The Global Risk Report 2019 menyatakan bahwa dalam lanskap risiko global, masyarakat cenderung terpolarisasi, dalam konteks ini terdapat perbedaan pendapat atau nilai yang sangat tajam (Folia, 2019). Global Risk Perception Survey (GRPS) mendefinisikan polarisasi terjadi akibat ketidak mampuan untuk mencapai kesepakatan karena adanya perbedaan nilai, pandangan politik atau agama yang ekstrem. Apabila melihat fenomena tersebut di negara Barat, hal ini juga berkelindan dengan tesis yang dikatakan oleh Lipset, yang menjelaskan bahwa tingkat keterlibatan individu dengan institusi keagaamaan memiliki dampak yang cukup kuat. Jika individu memiliki kedekatan yang cukup kuat dengan institusi agama, yang terjadi adalah pengaruh dari institusi keagamaan lebih mendominasi dalam perilaku politik individu (Lipset, 1960).

Persoalan lingkungan sosial juga berdampak dalam karakteristik yang terbentuk pada setiap individu. Pun demikian keagamaan memiliki pengaruh penuh, seperti halnya di negara Barat. Pengaruh agama yang dikeluarkan Gereja telah menjadi lingkungan sosial, terinstitusionalisasi secara kuat, membentuk sebuah jejaring sosial, sehingga menentukan preferensi politik individu (Forest, 2017). Dalam konteks pemilu kali ini, gejala demikian kian menguat ketika pelaksanaan proses kampanye, terdapat upaya kelompok-kelompok agama untuk memengaruhi proses politik 
elektoral. Ketika narasi agama muncul dalam pelaksanaan pemilu, beberapa partai politik mengambil kesempatan untuk menyuarakan narasi tersebut dan mereproduksi narasi tersebut secara terus-menerus. Salah satunya adalah fenomena dukungan salah satu parpol terhadap hasil Ijtima' Ulama yang isinya tertuang sebuah dukungan politik terhadap salah satu kandidat paslon. Ijtima' Ulama sendiri diselenggarakan oleh beberapa ormas Islam yakni salah duanya Front Pembela Islam (FPI) dan Gerakan Nasional Pembela Fatwa (GNPF).

Tabel 1. Sikap PKS Terhadap Gerakan Aksi Bela Islam

\begin{tabular}{|c|c|c|}
\hline No & Bentuk Aksi & Sikap PKS \\
\hline 1 & 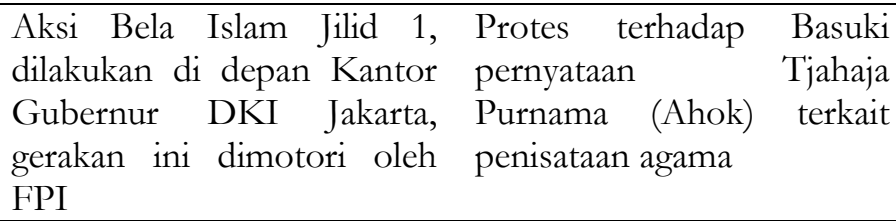 & $\begin{array}{l}\text { Menyatakan bahwa ini } \\
\text { bagian dari demokrasi, dan } \\
\text { tidak menyerukan apa pun } \\
\text { terhadap kader-kadernya. }\end{array}$ \\
\hline 2 & $\begin{array}{l}\text { Aksi Bela Islam Jilid 2, } \\
\text { dilakukan di depan Istana Ahok } \\
\text { Negara }\end{array}$ & $\begin{array}{l}\text { Keterlibatan kader PKS } \\
\text { merupakan hak pribadi }\end{array}$ \\
\hline 3 & $\begin{array}{lll}\text { Aksi Bela Islam Jilid 3, } & \text { Menuntut } & \text { untuk } \\
\text { diselenggarakan di Monas } & \begin{array}{l}\text { menonaktifkan } \\
\text { DKI Jakarta }\end{array} & \text { Gubernur }\end{array}$ & $\begin{array}{l}\text { Mengajak masyarakat untuk } \\
\text { berpartisipasi dalam aksi } \\
\text { tersebut }\end{array}$ \\
\hline 4 & $\begin{array}{llll}\text { Aksi Bela Islam Jilid 4, } & \text { Mengawal } & \text { jalannya } \\
\text { diadakan di Lapangan } & \text { persidangan Ahok } & \\
\text { Monas, dimotori oleh Forum } & & \\
\text { Umat Islam (FUI) } & \end{array}$ & $\begin{array}{l}\text { Memberikan izin kader PKS } \\
\text { untuk ikut dalam aksi } \\
\text { tersebut }\end{array}$ \\
\hline 5 & $\begin{array}{lll}\text { Aksi Bela Islam Jilid 5, } & \text { Meminta kepada DPR } \\
\text { diadakan di Gedung DPR RI } & \text { untuk menekan pemerintah } \\
& \text { melakukan apa yang sudah } \\
& \text { menjadi ketentuan undang- } \\
& \text { undang }\end{array}$ & $\begin{array}{l}\text { Mendukung gerakan } \\
\text { tersebut untuk hadir, karena } \\
\text { Gedung DPR merupakan } \\
\text { gedung dari rakyat }\end{array}$ \\
\hline 6 & $\begin{array}{l}\text { Aksi Bela Islam Jilid 6, Meminta memberhentikan } \\
\text { dengan kegiatan longmarch Ahok dari jabatannya } \\
\text { dari Masjid Istiqlal menuju } \\
\text { Istana Merdeka }\end{array}$ & $\begin{array}{l}\text { Meminta kepada pihak } \\
\text { kepolisian } \quad \text { untuk } \\
\text { membebaskan Sekjen FUI, } \\
\text { dan pemerintah segera } \\
\text { memberhentikan Ahok }\end{array}$ \\
\hline 7 & $\begin{array}{lll}\text { Aksi Bela Islam Jilid 7, } & \text { Mengawal jalannya proses } \\
\text { kegiatan longmarch dari Masjid } & \text { pembacaan r putusan } \\
\text { Istiqlal menuju Mahkamah } & \text { pengadilan terhadap kasus } \\
\text { Agung } & \text { Ahok } \\
\end{array}$ & $\begin{array}{l}\text { Mendukung gerakan } \\
\text { tersebut dengan sikap bahwa } \\
\text { masyarakat berhak } \\
\text { mengetahui proses hukum } \\
\end{array}$ \\
\hline 8 & $\begin{array}{lrlr}\begin{array}{l}\text { Reuni Aksi 212 Jilid 1, } \\
\text { dilakukan di Monas }\end{array} & \text { Berkumpul } & \text { untuk } \\
& \text { melakukan reuni, namun } \\
& \text { aksi ini dianggap memiliki } \\
& \text { muatan politis dalam } \\
& \text { pemilukada } \\
\end{array}$ & $\begin{array}{l}\text { Mengapresiasi jalannya aksi, } \\
\text { serta memberikan izin } \\
\text { kadernya untuk ikut sebagai } \\
\text { upaya meningkatkan } \\
\text { ekonomi Islam }\end{array}$ \\
\hline 10 & $\begin{array}{l}\text { Reuni Aksi } 212 \text { Jilid 2, Sebagai bentuk melawan } \\
\text { dilakukan di Monas, dengan sikap kriminalisasi ulama } \\
\text { beberapa kedatangan tokoh } \\
\text { politik }\end{array}$ & $\begin{array}{l}\text { Menyerukan kadernya untuk } \\
\text { ikut aksi reuni }\end{array}$ \\
\hline 11 & $\begin{array}{llll}\begin{array}{l}\text { Reuni Aksi } 212 \\
\text { dilakukan di Monas. }\end{array} & \text { 3ilid } & \begin{array}{l}\text { Meminta } \\
\text { memulangkan Habib Rizieq }\end{array} \\
\end{array}$ & cukan kad \\
\hline
\end{tabular}


PKS merupakan salah satu parpol yang mendukung rekomendasi Ijtima’ Ulama. Mereka menilai bahwa dengan memegang teguh dan menjunjung tinggi rekomendasi Ijtima' Ulama maka akan menciptakan bangsa yang lebih baik. Ketika memasuki momen-momen kampanye pemilu, aktivitas yang dilakukan PKS adalah menyerukan kader-kadernya hadir dalam acara Reuni 212 yang digelar di Monas. Kerja keras PKS menggiring kader-kadernya hadir karena beberapa alasan; Pertama, PKS ingin dianggap sebagai partai yang berjasa memenangkan paslon Prabowo-Sandi (Jpnn.com, 2018); Kedua, PKS ingin mendapatkan dukungan elektoral dari sejumlah Ulama yang tergabung dalam Aksi Bela Islam. Jajaran pengurus PA-212 dan GNPF Ulama mendatangi kantor PKS untuk memberikan dukungan terhadap partai dakwah berkontestasi dalam politik elektoral 2019 (Aliansyah, 2019). Hal ini sebagai upaya PKS dalam mendapatkan dukungan dari beberapa kelompok Islam yang tergabung dalam Gerakan Aksi Bela Islam.

Munculnya polarisasi yang terjadi di level masyarakat tidak bisa terlepas dari serangkaian Aksi Bela Islam yang berjilid-jilid seperti yang dijelaskan pada tabel 1. Bahkan, isu yang dihadirkan telah mengalami pergeseran isu secara bertahap. Isu yang dimunculkan pertama kali adalah pernyataan Ahok yang dianggap menista agama Islam. Dari aksi tersebut menuai banyak pro dan kontra. Bagi kubu pro, menganggap bahwa aksi tersebut bersifat politis karena ditujukan untuk menjatuhkan citra Ahok secara figur, dan juga selama kepemimpinan Ahok dinilai cukup baik dalam mengurus wilayah ibu kota. Sedangkan di kubu kontra, menganggap bahwa perilaku Ahok sudah tidak bisa ditolerir lagi, selain karena Ahok selalu menggunakan kekerasan secara verbal selama memimpin ibu kota, ia juga telah menista Islam.Pada Aksi Bela Islam jilid 1 sampai jilid 3, isu utamanya berupa meminta pihak kepolisian dan pemerintah untuk melakukan penangkapan terhadap Ahok. Dari serangkaian aksi tersebut, secara institusi, PKS tidak menyatakan sebagai bagian aksi tersebut. Namun membebaskan kader-kadernya untuk ikut aksi tersebut. PKS lebih mengajak masyarakat untuk berpartisipasi dalam Aksi Bela Islam melalui pernyataan Shohibul Iman yang menyerukan umat Islam untuk meluruskan niat, merapatkan barisan, dan saling tolong menolong. Juga tetap menjaga ketertiban umum sesuai dengan peraturan perundang-undangan yang berlaku (Okezone.com, 2016).

Aksi yang terjadi dalam jilid 4 hingga 7 diwarnai dengan pernyataan tegas PKS, secara institusional, mendukung Aksi Bela Islam lanjutan tersebut. Kemudian diiringi sikap politik yang tegas menolak penangkapan Sekjen FUI karena menganggap penangkapan tersebut bersifat politis. PKS juga menyatakan bahwa ucapan yang dilontarkan oleh Al Khatath bukan sebagai upaya makar terhadap pemerintahan Jokowi (Jpnn.com, 2017). Serta konsistensi PKS untuk segera mendesak pemerintah dan kepolisian mempercepat proses penangkapan Ahok yang dinilai belum mendapatkan kejelasan secara hukum.

Pada acara Reuni Alumni 212 dari jilid 1 sampai 3, PKS mencoba menyatakan sikap politiknya secara lebih jelas daripada aksi-aksi sebelumnya. Shohibul Iman menyerukan kaderkadernya datang dan menyukseskan agenda Reuni 212 tersebut (Septianto, 2018). PKS menegaskan akan terus menjaga dan mendukung para Ulama. Dukungan ini direalisasikan di antaranya dengan mendukung kegiatan-kegiatan yang diadakan para Ulama.

Jika dilihat dari pada pilkada dan pemilu serentak, sikap yang dihasilkan PKS terhadap gerakan Islam kemudian dapat diklasifikasikan menjadi tiga jenis sikap; Pertama, sikap PKS dengan mendukung gerakan tersebut sebagai bagian dari wajah demokrasi Indonesia. Kedua, PKS menyerukan umat Islam untuk berpartisipasi aktif dalam setiap agenda Aksi Bela Islam, Ketiga, 
PKS menyerukan untuk tidak memilih pemimpin yang telah melakukan kriminalisasi terhadap Ulama.

\section{PKS: Pertarungan Ideologis atau Bukan?}

Narasi Islam yang dibawa PKS berdampak positif setidaknya menjelang pemilu 2019. PKS juga diindikasikan sebagai salah satu organisasi politik yang menggunakan simbol dan wacana Islam untuk memobilisasi massa dalam Aksi Bela Islam jilid satu, dua, dan seterusnya (Pamungkas \& Octaviani, 2017). Bahkan, sepanjang Pilkada Serentak 2015-2018, terdapat isu agama yang kerap kali digunakan oleh kelompok Islam untuk menjatuhkan figur seorang kandidat. Dimulai dari ajakan untuk tidak memilih calon nonmuslim, seruan untuk memilih paslon muslim-muslim, isu pembangunan Gereja di wilayah mayoritas muslim (Shodiq \& Masykuri, 2018).

Di sisi lain, dalam perjuangan berbentuk kebijakan, PKS cenderung tidak mengambil sikap politik secara jelas terkait perda yang berbasis syariah. Temuan Buehler menjelaskan bahwa terdapat 7 dari 33 provinsi dan 51 dari sekitar 510 kabupaten yang menggunakan syariah sebagai aturan hukum justru didukung dan diperjuangkan oleh partai berbasis sekuler, seperti Golkar dan PDI-P (Lihat Buehler dalam Aminuddin \& Masykuri, 2016). Pada tahun 2013, salah satu politisi PKS, Jazuli Juwaini, menyatakan bahwa perda syariah bukan bagian dari Indonesia, karena menurutnya perda berbasis syariah ini akan menyulut kontroversi di kalangan publik (Imam, 2013). Namun sikap tersebut berbanding terbalik dengan fenomena akhir-akhir ini. PKS menyatakan bahwa persoalan perda syariah ini tidak bertentangan dengan nilai Pancasila. Nilai agama juga termaktub dalam sila pertama yakni Ketubanan Yang Maha Esa, hal ini dianggap sebagai landasan utama PKS dalam mendukung perda Syariah (CNNIndonesia.com, 2018).

Dari beberapa kasus di atas dapat dilihat bahwa PKS yang dinisbatkan sebagai partai dakwah, pada akhirnya, juga mengalami problematika yang cukup serius apabila dikaitkan dengan persoalan politik elektoral. Hal ini disampaikan oleh Muhtadi (2012) bahwa persaingan antarpartai dalam pemilu pasca-otoriter yang kian memanas memaksa PKS untuk mengutamakan dukungan elektoral jika dibandingkan memperkuat ideologi keagamaan. Partai Islam seperti PKB, cenderung lebih moderat dengan menggunakan asas Pancasila sebagai ideologi partai, demi mendapatkan dukungan elektoral. Hal tersebut menunjukkan kelangsungan hidup organisasi, khususnya partai, lebih diutamakan terutama menjelang pemilu.

Pertanyaan besar lalu muncul, apakah narasi identitas agama yang muncul merupakan sebuah perjuangan bersama atas nama ideologi bagi PKS, atau sebaliknya, narasi identitas Islam hanya dijadikan sebagai komoditas politik partai. Dari pemaparan data di atas menunjukkan bahwa eksistensi sikap PKS cenderung mengalami fluktuatif terhadap isu agama. Pada pertengahan tahun 2000-an, PKS cenderung fleksibel dan tidak memaksakan aturan hukum di Indonesia diterapkan berdasarkan satu agama tertentu. Namun semenjak menguatnya isu dan sentimen agama yang dipicu gerakan Islam kontemporer, PKS cenderung mengambil sikap sebaliknya. PKS mendukung secara penuh bahwa aturan hukum di Indonesia harus berbasis pada syariah-syariah Islam. Dalam konteks Pilkada Serentak, sikap politik PKS cenderung mengabaikan perda syariah, justru yang menyuarakan secara tegas terkait perda syariah muncul dari partai-partai sekuler. Dalam hal ini, penulis berargumen bahwa keterlibatan PKS dalam Aksi Bela Islam hanya mengambil momentum politik dari maraknya sentimen-sentimen agama, PKS hanya menjadi gerakan tersebut sebagai penopang keterpilihannya dalam Pemilu 2019. 


\section{Kesimpulan}

Gerakan aktivisme Islam baru-baru ini merupakan sebuah fenomena mobilisasi massa paling besar dalam sejarah politik Indonesia. Gerakan tersebut mampu menduduki Monas dengan massa jutaan yang tujuannya meminta pertanggung jawaban pernyataan Ahok yang dianggap menista Islam. Kehadiran gerakan tersebut kemudian menjadi momentum bagi partai politik untuk mendapatkan dukungan perolehan suara agar dapat terpilih di parlemen, salah satunya PKS. Sejak awal munculnya gerakan tersebut, PKS paling konsisten mendukung hingga akhir serta menyerukan kader-kadernya untuk ikut berpartisipasi terhadap jalannya gerakan tersebut. Tentu yang menjadi menarik adalah apabila kita tarik secara historis konsep pemikiran antara gerakan Islam baru dengan pemikiran politik PKS yang keduanya berasal dari pemkiran Islam Timur Tengah. Meskipun sebagian gerakan tersebut diisi oleh kalangan Islam tradisional, namun pelopor maupun inisiator gerakan tersebut mempunyai relasi pemikiran yang serupa dengan PKS.

Sentimen agama adalah salah satu indikator menguatnya politik identitas yang digunakan untuk memperkuat identifikasi pihak lawan dan kawan. Dalam konteks elektoral, isu agama sangat ampuh untuk mendelegitimasi lawan yang dianggap melawan titah langit sekaligus meningkatkan daya dukung elektoral terhadap partai yang menggunakannya. Narasi agama yang dibawa saat itu adalah menolak pemimpin birokrat yang beragama selain Islam. Dalam pilkada DKI Jakarta 2017, secara tidak langsung PKS mendukung untuk memberikan hukuman yang seadil-adilnya bagi Ahok yang dianggap melakukan penistaan terhadap Islam. Elite PKS juga menganggap bahwa menggunakan narasi agama sebagai strategi politiknya, yang secara tegas tidak menolak hadirnya politik identitas berbasis agama. Sikap politik PKS juga terhadap Aksi Bela Islam paling konsisten mendukung dari Aksi Bela Islam jilid pertama hingga Reuni Aksi Bela Islam ketiga. Selain itu, PKS menganggap strategi yang dijalankan adalah upaya positif menuju konsolidasi demokrasi.

Dari pemaparan data yang telah dijelaskan sebelumnya menunjukkan bahwa eksistensi sikap PKS cenderung mengalami fluktuatif terhadap isu agama. Pada pertengahan tahun 2000-an, PKS cenderung fleksibel dan tidak memaksakan aturan hukum di Indonesia diterapkan berdasarkan satu agama tertentu. Namun semenjak menguatnya isu dan sentimen agama yang dipicu gerakan Islam kontemporer, PKS cenderung mengambil sikap sebaliknya. PKS mendukung secara penuh bahwa aturan hukum di Indonesia harus berbasis pada syariah Islam.

\section{Daftar Pustaka}

Adiwilaga, R. (2017). Political islam movement and historical project of islamism enforcement in indonesia. Jurnal Wacana Politik, 2(1), 1-9.

Afala, L. M. (2018). Politik Identitas di Indonesia. Malang: UB Press.

Aliansyah, M. A. (2019). GNPF dan PA 212 Temui Elite PKS, Bahas Dukungan Politik dan Kasus Slamet Ma'arif. Retrieved from https://www.merdeka.com/peristiwa/gnpf-dan-pa-212temui-elite-pks-bahas-dukungan-politik-dan-kasus-slamet-maarif.html

Aminuddin, F. (2010). Reorganisasi Partai Keadilan Sejahtera Di Indonesia. Journal of Government and Politics, 1(1), 129-144. https://doi.org/10.18196/jgp.2010.0008

Aminuddin, M. F., \& Masykuri, R. (2016). Genealogi dan Transformasi Ideologi Partai berbasis Islam di Indonesia Pasca Orde Baru. ISLAMICA: Jurnal Studi Keislaman, 10(1), 27. https://doi.org/10.15642/islamica.2015.10.1.27-55

Arrobi, M. Z. (2020). Islamisme ala Kaum Muda Kampus: Dinamika Aktivisme Mahasiswa Islam di 
Universitas Gadjah Mada dan Universitas Indonesia di Era Pasca-Soeharto. Yogyakarta: Gadjah Mada University Press.

Bonasir, R. (2017). Dengan 212, umat Islam "ingin berkuasa lewat pilkada, pemilu dan pilpres." Retrieved November 12, 2019, from https://www.bbc.com/indonesia/indonesia42184928

Carvalho, J.-P. (2009). A Theory of The Islamic Revival. Retrieved from https://www.economics.ox.ac.uk/department-of-economics-discussion-paper-series/atheory-of-the-islamic-revival

CNNIndonesia.com. (2018). PKS soal PSI Tolak Perda Syariah: Hanya PKI yang Tolak Agama. Retrieved from https://www.cnnindonesia.com/nasional/20181113151857-32346207/pks-soal-psi-tolak-perda-syariah-hanya-pki-yang-tolak-agama

Crouch, H. (1979). Patrimonialism and Military Rule in Indonesia. World Politics, 31(4), 571-587. https://doi.org/doi:10.2307/2009910.

Folia, R. (2019). Global Risk Report 2019: Polarisasi Politik di Masyarakat Kian Tajam. Retrieved November 22, 2019, from https://www.idntimes.com/news/world/rosa-folia/globalrisk-report-2019-polarisasi-politik-di-masyarakat-kian-tajam/full

Forest, B. (2017). Electoral geography: From mapping votes to representing power. Geography Compass. https://doi.org/https://doi.org/10.1111/gec3.12352

Hadiz, V. R. (2019). Populisme Islam: di Indonesia dan Timur Tengah. Jakarta: Universitas Indonesia \& LP3ES.

Heryanto, A. (2018). Identitas dan Kenikmatan: Politik Budaya Layar Indonesia. Jakarta: Kepustaaan Populer Gramedia.

Horowitz, D. L. (1985). Ethnic Groups in Conflict. California: Univ of California Press.

Imam, P. (2013). Penyebutan Perda Syariah Tidak Tepat. Retrieved from https://nasional.kompas.com/read/2013/01/11/10350759/Penyebutan.Perda.Syariah. Tidak.Tepat

Jpnn.com. (2017). Politikus PKS Kecam Polisi Soal Penangkapan Sekjen FUI. Retrieved from https://www.jpnn.com/news/politikus-pks-kecam-polisi-soal-penangkapan-sekjen-fui

Jpnn.com. (2018). Bisa Jadi Ini Sebab PKS Ngebet agar Kadernya Ikut Reuni 212. Retrieved from https://www.jpnn.com/news/bisa-jadi-ini-sebab-pks-ngebet-agar-kadernya-ikut-reuni212

Junita, N. (2019). Ternyata, 2 Hal Ini Penyebab Perolehan Suara PKS Naik di Pemilu 2019. Retrieved from https://kabar24.bisnis.com/read/20190418/15/913205/ternyata-2-halini-penyebab-perolehan-suara-pks-naik-di-pemilu-2019

Kumparan. (2019). PKS, Meroket Berkat Bangkitnya Politik Identitas. Retrieved from https://kumparan.com/kumparannews/pks-meroket-berkat-bangkitnya-politikidentitas-1 qyoLqhS2mV

Kusumo, R., \& Hurriyah. (2018). Populisme Islam di Indonesia: Studi Kasus Aksi Bela Islam oleh GNPF-MUI Tahun 2016-2017. Jurnal Politik, 4(1), 87-114. https://doi.org/https://doi.org/10.7454/jp.v4i1.172

Lane, J.-E., \& Ersson, S. (1987). Politics and Society in Western Europe. London: Sage.

Lawson, K. (1980). Political Parties and Linkage. In K. Lawson (Ed.), Political Parties and Linkage (pp. 3-24). New Heaven, CT: Yale University Press. 
Lipset, S. M. (1960). Political Man: The Social Bases of Politics. Retrieved from http://www.archive.org/details/politicalmansociOOinlips

Maulidar, I. (2019). Mardani Ali Sera: Suara PKS Naik karena Efek 212. Retrieved from https:// nasional.tempo.co/read/1198032/mardani-ali-sera-suara-pks-naik-karena-efek212

Mietzner, M. (2008). Comparing Indonesia's party systems of the 1950s and the post-Suharto era: From centrifugal to centripetal inter-party competition. Journal of Southeast Asian Studies, 39(3), 431-453. https://doi.org/10.1017/S0022463408000337

Muhtadi, B. (2012). Dilema PKS: Suara dan Syariah. Jakarta: Kepustaaan Populer Gramedia.

Mujani, S., Liddle, R. W., \& Ambardi, K. (2019). Kaum Demokrat Kritis. Jakarta: Kepustaaan Populer Gramedia.

Mustika, Z. (2008). Metode Penelitian Kepustakaan. Jakarta: Yayasan Obor Indonesia.

Neidhardt, F., \& Rucht, D. (1993). Auf dem Weg in die "Bewegungsgesellschaft"? Über die Stabilisierbarkeit sozialer Bewegungen. Soziale Welt, 44, 305-326.

Okezone.com. (2016). PKS Ajak Warga Berpartisipasi dalam Aksi 212. Retrieved from https://nasional.okezone.com/read/2016/11/30/337/1554962/pks-ajak-wargaberpartisipasi-dalam-aksi-212

Pamungkas, A. S., \& Octaviani, G. (2017). Aksi Bela Islam dan Ruang Publik Muslim: Dari Representasi Daring ke Komunitas Luring. Jurnal Pemikiran Sosiologi, 4(2), 65. https://doi.org/10.22146/jps.v4i2.28581

Pepinsky, T. (2019). Pembelahan Agama dan Etnis dalam Pilpres 2019. Retrieved from https://tirto.id/pembelahan-agama-dan-etnis-dalam-pilpres-2019-eamN

PKS. (2019). Visi Misi Partai Keadilan Sejahtera. Retrieved from http://pks.id/content/visi-danmisi

Poguntke, T. (2000). Parteiorganisation im Wandel. Gesellschaftliche Verankerung und organisatorische Anpassung im europäischen Vergleich. Wiesbaden: Westdeutscher Verlag.

Poguntke, T. (2005). Parties without firm social roots? Party organisational linkage. In K. R. Luther \& F. Muller-Rommel (Eds.), Political Parties in the New Europe: Political and Analytical Challenges (pp. 43-62). Oxford: Oxford University Press.

Poguntke, T. (2006). Political parties and other organizations. In R. S. Katz \& W. Crotty (Eds.), Handbook of Party Politics (pp. 396-405). London: Sage Publications.

Poltracking. (2017). Peta Elektabilitas Kandidat Gubernur dan Preferensi Pemilih. (November), 1-63. Retrieved from https://poltracking.com/wp-content/uploads/2017/12/LaporanSurvei-Poltracking-Pilkada-Jabar-2018-Peta-Elektabilitas-Kandidat-Gubernur-danPreferensi-Pemilih.pdf

Rahmat, M. I. (2008). Ideologi politik PKS : dari masjid kampus ke gedung parlemen. Yogyakarta: LKIS.

Septianto, B. (2018). PKS Serukan Kadernya Ikut Reuni 212, Kubu Jokowi: Makin Jelas Ada Motif Politik.

Retrieved from https://news.okezone.com/read/2018/11/29/605/1984314/pks-serukan-kadernyaikut-reuni-212-kubu-jokowi-makin-jelas-ada-motif-politik

Shodiq, F., \& Masykuri, R. (2019). Marketing Isu Agama Daam Pemilihan Kepala Daerah di Indonesia 2015-2018. Jurnal Penelitian Politik, 15(726).

Stokke, K. (2013). Conceptualizing the politics of citizenship. PCD Journal, 25(iv), 1-46. 
This is an open access article

Under the CC-BY-SA license

Viva.co.id. (2017). VIDEO: Penyebar Selebaran SARA Pilkada DKI Ditangkap. Retrieved from https://www.viva.co.id/berita/metro/352574-video-penyebar-selebaran-sara-pilkadadki-ditangkap

Webb, P. (1992). Trade Unions and the British Electorate. Aldershot: Dartmouth. 